\title{
İlkokullarda Örgütsel İletişim ile Öğretmenlerin İş Motivasyonu
} Arasındaki İlişskiler*

\section{The Relationships between Organizational Communication and Work Motivation of Teachers at Primary Schools}

\author{
Tevfik Uzun ${ }^{l}$ \\ Ahmet Ayık ${ }^{2}$ \\ Güven Özdem ${ }^{3}$
}

Alıntılama: Uzun, T, Ayık, A., \& Özdem, G. (2019). Okullarda örgütsel iletişim ile öğretmenlerin iş motivasyonları arasındaki ilişkiler. Ulusal Eğitim Akademisi Dergisi (UEAD), 3(1), 26-40.

Geliş tarihi:

26 Aralık 2018

Kabul tarihi:

28 Şubat 2019

(C) UEAD 2019

Tüm haklarl saklıdır.
Özet: $\mathrm{Bu}$ araştırmada ilkokullarda örgütsel iletişim ile öğretmenlerin iş motivasyonu arasındaki ilișkilerin incelenmesi amaçlanmıștır. Araștırmanın örneklem grubunu, 2014- 2015 eğitim öğretim yılında Erzurum ili Palandöken ilçe merkezindeki Millî Eğitim Bakanlığına bağlı kamu ilkokullarında görev yapmakta olan n=234 öğretmen oluşturmaktadır. Araştırmada ilişkisel tarama modeli kullanılmıştır. Araştırmada veri toplama aracı olarak örgütsel iletişim için Celep (2000) tarafından geliştirilen "İletişim Ölçeği” kullanılmıştır. Öğretmenlerin iş motivasyonlarını belirlemek için ise Aksoy (2006) tarafından geliştirilen "İş Motivasyonu" ölçeği kullanılmıştır. Verilerin analizinde; yüzde, frekans, aritmetik ortalama, standart sapma, korelasyon analizi, basit ve doğrusal regresyon analizi kullanılmıştır. Araştırma sonuçları, ilkokullarda örgütsel iletişim ile öğretmenlerin iş motivasyonları arasında ilişki olduğunu ortaya koymaktadır. Ayrıca okullarda gerçekleşen örgütsel iletişim süreci, öğretmenlerin iş motivasyonlarını anlamlı bir şekilde yordamaktadır

Anahtar kelimeler: İlkokul, öğretmen, örgütsel iletişim, iş motivasyonu.

Received:

26 December 2018

Abstract: This paper studies the relationship between organizational communication and work motivation of teachers at primary schools. The sample of the study includes 234 teachers employed in public schools in Palandoken County in Erzurum in 20142015 academic year. Correlational survey model was applied to the study. As a data

Accepted:

28 February 2019 gathering tool for organizational communication, 'Communication Scale' developed by Celep (2000) was used. For teachers motivation 'Work Motivation' scale developed by Aksoy (2006) was applied. Analysing the gathered data involved

\footnotetext{
* Bu araştırma, 13-15 Ekim 2016 tarihinde Rize'de yapılan VI. Uluslararası Eğitimde Araştırmalar Kongresi'nde sözlü bildiri olarak sunulmuştur.

${ }^{1}$ Dr. Öğr. Üyesi, Giresun Üniversitesi, tevfik_uzun@yahoo.com, ORCID ID: 0000-0002-6505-2421.

${ }^{2}$ Doç. Dr., Atatürk Üniversitesi, ahmet.ayik@atauni.edu.tr, ORCID ID: 0000-0002-2885-947X.

${ }^{3}$ Doç. Dr., Giresun Üniversitesi, guven.ozdem@giresun.edu.tr, ORCID ID: 0000-0001-5617-5780.
} 
(C) UEAD 2019 All rights reserved. percentage, frequency, mean, standard deviation, correlation, simple and linear regression analysis were all applied. The findings show that there is a relationship between organizational communication and teacher motivation in primary schools. Besides, the process of organizational communication predicts teachers motivation for work.

Keywords: Primary schools, teacher, organizational communication, work motivation.

\section{Giriş}

İletişim; okulların etkinliğgi, verimliliği ve amaçlarını gerçekleştirmede başlıca rol oynayan süreçlerden biridir ve okullar için hayati bir öneme sahiptir. İletişim, okulda var olan planlama, örgütleme, iş bölümü yapma, yönlendirme, işbirliği ve raporlama gibi süreçlerin çoğu ile bağlantılıdır. Okullarda örgütsel iletişimin amacı, hedefe ulaşmada gerekli olan bilgi aktarımını sağlamaktır (Lunenburg ve Ornstein, 2013). Bu bağlamda örgütsel iletişim, örgütün iç paydaşları arasındaki bilgi ve ileti alışverişini ifade etmektedir. Örgütsel iletişim, iki veya daha fazla insan arasında anlaşmak ve bilgi alışverişinde bulunmak için kullanılan bir süreçtir. Örgütsel iletişimin amacı genellikle bireylerin motivasyon ve davranışlarını etkilemektir (Daft, 2005). Örgütsel iletişimle örgütlerin amaç ve hedeflerine ulaşması, örgütün uyum içinde çalışması, örgütün tüm birimleri arasındaki koordinasyon, bilgi akışı, çalışanların ilişkilerinin düzenlenmesi, örgütsel bütünleşme, eğitim, karar alma-verme ve denetim sağlanmaktadır. Kısaca, tüm örgütsel ve yönetsel etkinlikler, örgütsel iletişim aracılığıyla gerçekleşmektedir (Tutar, 2003; Robbins ve Judge, 2012; Sabuncuoğlu ve Gümüş, 2008). Ortak bir amaç, bu amaca ulaşmaya istekli çalışanlar ve iletişim, bir örgütün temel öğeleridir. Örgüt içinde etkin bir iletişim olmaksızın ortak amacın yayılması, benimsenmesi ve bu amaca ulaşmak isteyen çalışanların çabalarının koordine edilmesinden bahsedilemez (Aydın, 2010).

Örgütsel amaçlar için çalışanların etkin ve verimli çalışmalarının sağlaması gerekmektedir. Çalışanların etkin ve verimli çalışmaları ise çalışanların yüksek motivasyonlarıyla gerçekleşebilmektedir. İletişim, çalışanlara ne yapmaları gerektiği, nasıl daha iyi yapacakları ve düşük performans gösterdiklerinde bunu nasıl geliştirebilecekleri konusunda açıklık sağladığı içinonların motivasyonlarını artırıcı bir güç olarak değerlendirilmektedir (Robbins ve Judge, 2012). Çalışanlara örgütsel amaçların benimsetilmesinde ve çalışanların örgütsel amaçlar doğrultusunda motive edilmelerinde iletişim etkin bir rol oynamaktadır. Bu bağlamda örgütsel iletişim çalışanlar için önemli bir motivasyon aracı olabilmektedir. Alanyazında örgütsel iletişim ile iş motivasyonu ve işgören performansı (Rajhans, 2012), çalışanların mutluluğu ve iş tutumları arasında (Proctor, 
2014), iş tatmini arasında (Eroğluer, 2011; Sharma, 2015; Karcıoğlu, Timuroğlu ve Çınar, 2009; Proctor, 2014), işgören bağlılığı arasında (De Ridder 2004; Taşlıyan ve Hırlak, 2015), örgütsel vatandaşlık (Demirel, Seçkin ve Özçınar, 2011; Uslu ve Balcı; 2012) ile pozitif; örgütsel iletişim ile örgütsel sinizm arasında negatif ilişki (Ayık, 2015; Tınaztepe, 2012) bulunmaktadır.

Motivasyon kavramı; harekete geçmek, teşvik etmek ve hareket etmek anlamlarına gelen Latince "movere" kelimesinden türetilmiştir. İnsanların bir işi yapabilmesi için gerekli olan çabanın ve enerjinin yaratılması işlemi motivasyonu ifade etmektedir (Güney, 2011). Başka bir tanıma göre motivasyon, belirli bir amaca ulaşmaya yönelik olarak enerji, istikamet ve kararlılık içeren kişisel çabaların ortaya konduğu süreçtir (Robbins, Decenzo ve Coulter, 2013). Çalışanın iş motivasyonu ise bireyin işle ilgili davranışlarını harekete geçiren ve bu davranışların biçimini, yönünü, yoğunluğunu ve süresini belirleyen; bireyin hem içsel hem de dişsal enerjik güçlerinin bir bütünüdür (Pinder, 2014). İş motivasyonu, çalışanların örgütte başarılı ve verimli olmalarına, bireysel doyuma ulaşmalarına yardımcı olmaktadır. Motive olan kişi, amaç ve hedefe ulaşmak, başarılı olmak için gerekli gücü sağlamış olmaktadır (Genç 2007, 261). Motivasyon sürecinde; örgütsel amaçlar, kişilerin amaçları, kişilerin gösterdiği çaba rol oynamaktadır. Kişilerin ihtiyaçları, örgütsel amaçlarla örtüşmelidir. Alanyazında öğretmenlerin iş motivasyonu ile örgütsel ve mesleki bağlılık arasında pozitif bir ilişki olduğu görülmektedir (Ertürk, 2014; Canrinus, Helms-Lorenz, Beijaard, Buitink ve Hofman, 2012; Oran, Güler ve Bilir, 2016). Araştırmalar okullarda iş motivasyonu ile örgütsel sağlı arasında pozitif yönde anlamlı ilişkiler olduğunu göstermektedir (Güçlü, Recepoğlu ve Kılınç, 2014). Okul müdürlerinin liderlik sitilleri ile öğretmenlerin iş motivasyonları arasında da (Wasserman, Ben-eli, Yehoshua ve Gal, 2016; Eyal ve Roth, 2010; Leithwood, Steinbach, ve Jantzi, 2012) pozitif ilişkiler bulunmaktadır. Ayrıca öğretmen iş motivasyonu öğrenci motivasyonu ile ilişkilidir (Atkinson, 2000). Öğretmenlerin iş motivasyonu, iş doyumları ile pozitif (Canrinus ve diğerleri, 2012; Yavuz ve Karadeniz, 2009; Davis ve Wilson, 2000; Bishay, 1996); iş stresi (Davis ve Wilson, 2000) ve tükenmişlik (Eyal ve Roth, 2010; Anderson ve Iwanicki, 1984) ile negatif ilişkidir

Eğitimin toplumsal, kültürel ve ekonomik amaçları okullar aracılığı ile gerçekleştirilmektedir. Okulların üretim, düzenleme, yenilik, sosyalleşme ve bakım gibi amaçlara hizmet etmesi için iletişimden üst seviyelerde ortak anlamlar oluşturması beklenmektedir. Okullardaki hedeflere ulaşmak için bireylerin eylemlerine ihtiyaç vardır. Hedefe yönelik davranışlar iletişim yoluyla ortaya çıkarılmaktadır (Hoy ve Miskel, 2010). Okul yöneticileri okulun 
amaçlarını tek başlarına gerçekleştirememektedir. İletişimin sosyalleşme ve sürdürülebilir amaçları, bireylerin kendi kendilerine saygılarını, kişilerarası ilişkilerini ve bireysel hedeflerini okulun amaçları ile birleştirmek için motivasyonlarını etkilemektedir (Hoy ve Miskel 2010). Eğitim ve öğretim, eğitimin tüm paydaşları arasındaki sağlıklı iletişimle mümkündür. Paydaşlarla yürüyen bu süreçte öğretmen, bazı zamanlarda çeşitli sebeplerden dolayı motivasyon kaybına uğrayabilmekte ve iş verimsizliği yaşayabilmektedir. Öğretmenin verimliliğii, kendisini eğitim sürecine motive edebildiği ölçüde ortaya çıkmaktadır (Büyükses, 2010). Öğretmenler okulların amaçlarına yönelik olarak eğitime ve öğretime ilişkin temel görevlerini yerine getirmeye motive olurlarken iletişim ortamından etkilenebilmektedir.

Araştırmanın amacı, öğretmenlerin görüşlerine göre örgütsel iletişim ile öğretmenlerin iş motivasyonları arasındaki ilişkilerin incelenmesidir.

Bu amaca ulaşmak için şu sorulara cevap aranmıştır.

1. İlkokul öğretmenlerinin okullarındaki örgütsel iletişime ilişkin görüşleri ile iş motivasyonları arasında anlamlı bir ilişki var mıdır?

2. İlkokul öğretmenlerinin okullarındaki örgütsel iletişime ilişkin görüşleri iş motivasyonlarını anlamlı bir şekilde yordamakta mıdır?

\section{Yöntem}

Araştırma Modeli

İlkokul öğretmenlerinin okullarındaki örgütsel iletişim ile iş motivasyonları arasındaki ilişkilerin incelendiği bu araştırmada, ilişkisel tarama modeli kullanılmıştır.

\section{Çalışma Grubu}

Araştırmanın örneklem grubunu 2015 yılında Erzurum ili Palandöken ilçe merkezindeki Milli Eğitim Bakanlığına (MEB) bağlı kamu ilkokullarında görev yapmakta olan öğretmenler oluşturmaktadır. Örneklem grubunu basit tesadüfi örnekleme yöntemi ile belirlenen 16 ilkokulda görev yapan n=234 öğretmen oluşturmaktadır. Araştırmaya katılan öğretmenlerin 87'si erkek (\% 34.4) erkek, 166'sı (\% 65.6) kadındır. 1-5 yıl arasında kıdemi olan 44 (\% 17.4), 6-10 yıl arasında kıdemi olan 67 (\% 26.5), 11-20 yıl arasında kıdemi olan 73 (\% 28.9) ve 21 yılın üzerinde kıdemi olan öğretmen sayısı ise 22'dir (\% 8.7). Ayrıca, öğretmenlerin 231'i lisans (\% 91.3), 22'si lisansüstü (\% 8.7) düzeyinde eğitim almıştır.

Veri Toplama Araçları 
Araştırmada veri toplama aracı olarak, "İletişim Ölçeği” ve “İş Motivasyonu” ölçeği kullanılmıştır.

\section{Örgütsel İletişim Ölçeği}

Celep (2000) tarafından geliştirilen ölçeğin geçerlik ve güvenirlik çalışmaları Erel-Yetim (2010) tarafından yapılmıştır. 34 maddelik ölçek 5'li Likert tipindedir. Analiz sonuçlarına göre ölçek, tutum ve davranışa yönelik iletişim, bilgilendirmeye yönelik iletişim, geribildirim ve göreve yönelik iletişim olarak adlandırılan dört alt boyuttan oluşmaktadır. Ölçek maddelerinin faktör yük değerleri 0.47 ile 0.83 arasında değişmektedir. Örgütsel iletişim ölçeğinin bütününe ilişkin güvenirlik katsayısı Erel-Yetim (2010) tarafından $\alpha=.91$ olarak hesaplanmıştır. Araştırmacılar tarafından yapılan güvenirlik analizi (Cronbach Alpha) sonuçlarına göre ölçeğin bütününe ilişkin alfa $\alpha=.98$; Bilgilendirmeye Yönelik İletişim alfa $\alpha=.96$, Göreve Yönelik İletişim alfa $\alpha=.93$, Geri Bildirim alfa $\alpha=.95$, Tutum ve Davranışa Yönelik İletişim alfa $\alpha=.96$ olarak bulunmuştur

\section{İş Motivasyonu Ölçeği}

Ölçek, Aksoy (2009) tarafından geliştirilmiştir. Toplamda 18 maddelik ölçek 5'li Likert tipindedir. Yılmaz (2009) tarafından yapılan faktör analizi sonuçlarına göre ölçek ekip uyumu (toplam varyansa katkısı \% 30.8), işle bütünleşme (toplam varyansa katkısı \% 12.04), kuruma bağlılık (toplam varyansa katkısı \% 10.04) ve kişisel gelişim (toplam varyansa katkısı \% 8.41) olmak üzere dört boyutlu bir yapıdadır. Ölçeğin Ekip Uyumu alt boyutu için faktör yük değeri .49-.78 arasında, İşle Bütünleşme boyutu için .54-.78 arasında, Kuruma Bağlılık boyutu için .59-.81 arasında, Kişisel Gelişim boyutu için .43-.73 arasındadır. Ölçeğin KMO değeri .78 olarak hesaplanmıştır. Ölçeğin güvenirlik katsayısı Yıılmaz (2009) tarafından. $\alpha=.82$ ve Aksoy (2009) tarafından $\alpha=$.79olarak hesaplanmıştır. Ölçek, Yılmaz'ın (2009) kullandığı haliyle 4 boyutlu bir yapıda kullanılmıştır. Ölçeğe yeniden güvenirlik analizi (Cronbach Alpha) yapılmıştır. Araştırmacılar tarafından yapılan analizi (Cronbach Alpha) sonuçlarına göre ölçeğin bütününe ilişkin alfa $\alpha=.97$, Ekip Uyumu alfa $\alpha=.94$, İşle Bütünleşme alfa $\alpha=.90$, Kuruma Bağlılık alfa $\alpha=.85$, Kişisel Gelişim alfa $\alpha=.90$ olarak hesaplanmıştır.

\section{Verilerin Analizi}

Verilerin analizinde; aritmetik ortalama, yüzde, frekans, standart sapma, korelasyon analizi, basit ve çoklu doğrusal regresyon analizi kullanılmıştır. Değişkenler arasındaki korelasyon ve regresyonlara geçilmeden önce kayıp veri analizi, uç değerler analizi yapılmış, normallik, doğrusallık ve çoklu bağlantı problemi incelenmiştir. Verilerin normalliğini test etmek amaciyla 
ve basıklık ve çarpıklık değerlerinden yararlanılmıştır. Bu araştırmada örgütsel iletişime ait ( toplam puan) çarpıklık katsayısı -0.69, basıklık katsayısı 0.35; Bilgilendirmeye Yönelik İletişim boyutunun çarpıklık katsayısı -0.75, basıklık katsayısı 0.14; Göreve Yönelik İletişim boyutunun çarpıklık katsayısı -1.19, basıklık katsayısı 1.24; Geri Bildirim boyutunun çarpıklık katsayısı -0.87, basıklık katsayısı -0.09; Tutum ve Davranışa Yönelik İletişim boyutunun çarpıklık katsayısı -0.77, basıklık katsayısı -0.43 olarak hesaplanmıştır. İş motivasyonuna (toplam puan) ilişskin çarpıklık katsayıs1 -0.65, basıklık katsayısı 0.72; Ekip Uyumu boyutunun çarpıklık katsayısı -0.90, basıklık katsayısı 0.05; İşle Bütünleşme boyutunun çarpıklık katsayısı -0.82, basıklık katsayısı -0.13; Kuruma Bağlılık boyutunun çarpıklık katsayısı -0.81, basıklık katsayısı -0.34 ve Kişisel Gelişim boyutunun çarpıklık katsayısı -0.87 , basıklık katsayısı -0.14 olarak hesaplanmıştır. Bu değerler normallik sayıltılarını karşılamaktadır. Verilerin doğrusallığı sayıltısını incelemek üzere de saçılma diyagramı matrisi kullanılmıştır. Matriste yer alan değişken çiftlerinin oluşturduğu şekillerin elipse yakın olduğu gözlenmiştir. $\mathrm{Bu}$ inceleme verilerin doğrusallık sayıltılarını karşıladığını göstermektedir. Değişkenler arasında çoklu bağlantı problemi olup olmadığını incelemek üzere bağımsız ve bağımlı değiş̧kenler arasında ikili korelasyonlar incelenmiş, ilişkilerin çoklu bağlantı problemi oluşturacak kadar yüksek değerde olmadığı tespit edilmiştir.

\section{Bulgular}

Araştırmanın değişkenlerine ilişkin betimsel istatistikler ve değişkenler arasındaki ilişkiler Tablo 1'de verilmiştir.

Tablo 1. Ortalama ve Standart Sapma Değerleri ile Değişkenler Arasındaki İlişkiler

\begin{tabular}{|c|c|c|c|c|c|c|c|c|c|c|c|c|}
\hline Değişkenler & $\overline{\mathbf{x}}$ & Ss & 1 & $1 \mathbf{a}$ & $1 \mathbf{b}$ & 1c & 1d & 2 & $\mathbf{2 a}$ & $2 \mathbf{b}$ & $2 c$ & $2 d$ \\
\hline 1.Örgütsel İletişim & 4.18 & .88 & - & & & & & & & & & \\
\hline 1a. Göreve Yön. İltş. & 4.21 & .89 & $.91 * *$ & - & & & & & & & & \\
\hline 1b. Bilgi. Yön. İltş. & 4.15 & .87 & $.97 * *$ & $.91 * *$ & - & & & & & & & \\
\hline 1c.Geri Bildirim & 4.15 & .90 & $.95 * *$ & $.81 * *$ & $.89 * *$ & - & & & & & & \\
\hline 1d.Tut. Dav.Yön. İltş. & 4.18 & .88 & $.96 * *$ & $.82 * *$ & $.89 * *$ & $.90 * *$ & - & & & & & \\
\hline 2.İş Motivasyonu & 4.13 & .91 & $.81 * *$ & $.73 * *$ & $.78 * *$ & $.74 * *$ & $.82 * *$ & - & & & & \\
\hline 2a.Ekip Uyumu & 4.10 & .98 & $.79 * *$ & $.73 * *$ & $.78 * *$ & $.70 * *$ & $.78 * *$ & $.97 * *$ & - & & & \\
\hline 2b.İşle Bütünleşme & 4.22 & .84 & $.76^{* *}$ & $.68 * *$ & $.72 * *$ & $.72 * *$ & $.77 * *$ & $.93 * *$ & $.88 * *$ & - & & \\
\hline 2c.Kuruma Bağ. & 4.16 & .93 & $.76^{* *}$ & $.66^{* *}$ & $.73^{* *}$ & $.67 * *$ & $.78^{* *}$ & $.93^{* *}$ & $.90 * *$ & $.85^{* *}$ & - & \\
\hline 2d.Kişisel Gelişim & 4.13 & .98 & $.71 * *$ & $.62 * *$ & $.66^{* *}$ & $.64 * *$ & $.75^{* *}$ & $.93 * *$ & $.89 * *$ & $.84 * *$ & $.84 * *$ & - \\
\hline
\end{tabular}

$* * \mathrm{p}<.01 ; * \mathrm{p}<.05$ 
Tablo 1 incelendiğinde, öğretmenlerin görüşlerine göre örgütsel iletişim (toplam puan) genel ortalamaları $\bar{x}=4.18$ olarak; iş motivasyonları (toplam puan) genel ortalamaları da $\bar{x}=4.13$ olarak hesaplanmıştır. Öğretmenlerin örgütsel iletişimin göreve yönelik iletişim boyutuna ilişkin ortalamaları ( $\bar{x}=4.21)$ örgütsel iletişimin diğer boyutlarına göre daha yüksektir. Öğretmenlerin iş motivasyonunun işle bütünleşme alt boyutuna ilişkin ortalamaları $(\overline{\mathrm{x}}=4.22)$ iş motivasyonun diğer boyutlarına göre daha yüksektir.

Değişkenler arasındaki korelasyon katsayıları incelendiğinde, örgütsel iletişim (toplam puan) ile öğretmenlerin iş motivasyonları (toplam puan) arasında $(\mathrm{r}=.81, \mathrm{p}<0.01)$ pozitif yönde anlamlı bir ilişki olduğu görülmektedir. Ayrıca, örgütsel iletişimin tüm alt boyutlarının, iş motivasyonun alt boyutları ile pozitif yönde anlamlı ilişkiler içinde olduğu görülmektedir. Örgütsel iletişim ile iş motivasyonun alt boyutları arasındaki en güçlü ilişkiler; bilgilendirmeye yönelik iletişim ile ekip uyumu $(\mathrm{r}=.78, \mathrm{p}<.01)$, tutum ve davranışa yönelik iletişim ile ekip uyumu $(\mathrm{r}=$ $.78, \mathrm{p}<.01)$, tutum ve davranışa yönelik iletişim ile kuruma bağll lık $(\mathrm{r}=.78, \mathrm{p}<.01)$ ve tutum ve davranışa yönelik iletişim ile işle bütünleşme $(\mathrm{r}=.77, \mathrm{p}<.01)$ arasında gerçekleşmiştir.

Örgütsel iletişim alt boyutları ile iş motivasyonunun alt boyutları arasında önemli doğrusal ilişkiler bulunmaktadır. Örgütsel iletişim alt boyutlarının iş motivasyonunun Ekip Uyumu alt boyutunu yordamasına ilişkin bulgular Tablo 2'de verilmiştir.

Tablo 2. Örgütsel Illetişim Alt Boyutlarının Işs Motivasyonun Ekip Uyumu Alt Boyutunu Yordamasina İlişkin Çoklu Doğrusal Regresyon Analizi Sonuçları

\begin{tabular}{llllll}
\hline Değişkenler & B & SH & 及 & t & p \\
\hline Sabit & .25 & .18 & & 1.39 & .16 \\
Göreve Yönelik İletişim & .10 & .09 & .09 & 1.09 & .27 \\
Bilgilendirmeye Yönelik İletişim & .47 & .13 & .42 & 3.49 & .00 \\
Geri Bildirim & .32 & .10 & .29 & 3.07 & .00 \\
Tutum ve Davranışa Yönelik İletişim & .66 & .10 & .59 & 6.03 & .00
\end{tabular}

Tablo 2'ye göregöreve yönelik iletişim, bilgilendirmeye yönelik iletişim, geri bildirim ve tutum ve davranışa yönelik iletişim değişkenleri ile ekip uyumu arasında anlamlı bir ilişki bulunmaktadır $\left(\mathrm{R}=.81^{\mathrm{a}} \mathrm{R}^{2}=.66 \mathrm{~F}=123.45 \mathrm{p}<.05\right)$. Bilgilendirmeye Yönelik İletişim $(\beta=.42, p$ $<.05)$, Geri Bildirim $(\beta=.29, p<.05)$ ve Tutum ve Davranışa Yönelik İletişim $(\beta=.59, p<.05)$ değişkenlerinin ekip uyumunu yordama gücü istatistiksel olarak anlamlı bulunmuştur. Bu üç değişken birlikte Ekip Uyumu toplam varyansının yaklaşık \% 66'sını açılamaktadır. Göreve yönelik iletişim ise ekip uyumu üzerinde anlamlı bir etkiye sahip değildir. 
Örgütsel iletişim alt boyutlarının iş motivasyonunun İşle Bütünleşme alt boyutunu yordamasına ilişkin bulgular Tablo 3 'te verilmiştir.

Tablo 3. Örgütsel İletişim Alt Boyutlarının İ̧̧ Motivasyonun Işle Bütünleşme Alt Boyutunu Yordamasına İlişkin Çoklu Doğrusal Regresyon Analizi Sonuçları

\begin{tabular}{llcccc}
\hline Değişkenler & B & SH & $\boldsymbol{\beta}$ & $\mathbf{t}$ & \multicolumn{1}{c}{ t } \\
\hline Sabit & .99 & .17 & & 5.80 & .00 \\
Göreve Yönelik İlet. & .11 & .09 & .12 & 1.26 & .20 \\
Bilgilendirmeye Yönelik İlet. & .02 & .12 & .03 & .22 & .82 \\
Geri Bildirim & .08 & .09 & .09 & .87 & .38 \\
Tutum ve Dav. Yönelik İlet. & .53 & .10 & .55 & 5.19 & .00 \\
\hline
\end{tabular}

$\mathrm{R}=0.77^{\mathrm{a}} \mathrm{R}^{2}=0.60 \mathrm{~F}=94.21 \mathrm{p}=0.00$

Tablo 3'e göre göreve yönelik iletişim, bilgilendirmeye yönelik iletişim, geri bildirim ve tutum ve davranışa yönelik iletişim değişkenleri ile işle bütünleşme arasında anlamlı bir ilişki bulunmaktadır $\left(\mathrm{R}=.77^{\mathrm{a}} \mathrm{R}^{2}=.60 \mathrm{~F}=94.21 \mathrm{p}<.05\right)$. Tutum ve Davranışa Yönelik İletişim $(\beta=.55$, $p<.05)$ değişkeninin işle bütünleşmeyi yordama gücü istatistiksel olarak anlamlı bulunmuştur. Bu değişken işle bütünleşme toplam varyansının yaklaşık \% 60’’nı açıklamaktadır. Göreve yönelik iletişim, bilgilendirmeye yönelik iletişim, geri bildirim ise işle bütünleşme üzerinde anlamlı bir etkiye sahip değildir.

Örgütsel iletişim alt boyutlarının iş motivasyonunun Kuruma bağlılık alt boyutunu yordamasına ilişkin bulgular Tablo 4'te verilmiştir.

Tablo 4. Örgütsel İletişim Alt Boyutlarının İş Motivasyonunun Kuruma Bağlılık Alt Boyutunu Yordamasına İlişkin Çoklu Doğrusal Regresyon Analizi Sonuçları

\begin{tabular}{llcccc}
\hline Değişkenler & B & SH & $\boldsymbol{\beta}$ & t & p \\
\hline Sabit & .69 & .18 & & 3.81 & .00 \\
Göreve Yönelik İletişim & .07 & .09 & .06 & .73 & .46 \\
Bilgilendirmeye Yönelik İlet. & .40 & .13 & .38 & 2.97 & .00 \\
Geri Bildirim & .33 & .10 & .32 & 3.20 & .00 \\
Tutum ve Dav. Yönelik İlet. & .83 & .10 & .79 & 7.66 & .00 \\
\hline
\end{tabular}

$$
\mathrm{R}=.79^{\mathrm{a}} \mathrm{R}^{2}=.63 \quad \mathrm{~F}=106.40 \quad \mathrm{p}=0.00
$$

Tablo 4'e göre göreve yönelik iletişim, bilgilendirmeye yönelik iletişim, geri bildirim ve tutum ve davranışa yönelik iletişim değişkenleri ile kuruma bağlılık arasında anlamlı bir ilişki bulunmaktadır $\left(\mathrm{R}=.79^{\mathrm{a}} \mathrm{R}^{2}=.63 \mathrm{~F}=106.40 \mathrm{p}<.05\right)$. Bilgilendirmeye Yönelik İletişim $\left(\beta=.38, p^{<}\right.$ $.05)$, Geri Bildirim $(\beta=.32, p<.05)$ ve Tutum ve Davranışa Yönelik İletişim $(\beta=.79, p<.05)$ değişkenlerinin kuruma bağlılığı yordama gücü istatistiksel olarak anlamlı bulunmuştur. Bu üç değişken birlikte kuruma bağlılık toplam varyansının yaklaşık \% 63’ünü açıklamaktadır. Göreve yönelik iletişim ise kuruma bağlılık üzerinde anlamlı bir etkiye sahip değildir. 
Örgütsel iletişim alt boyutlarının iş motivasyonunun Kişisel Gelişim alt boyutunu yordamasına ilişkin bulgular Tablo 5 'te verilmiştir.

Tablo 5. Örgütsel Illetişim Alt Boyutlarının İş Motivasyonunun Kişisel Gelişim Alt Boyutunu Yordamasina İlişkin Çoklu Doğrusal Regresyon Analizi Sonuçları

\begin{tabular}{llcccc}
\hline Değişkenler & B & SH & B & t & p \\
\hline Sabit & .65 & .20 & & 3.19 & .00 \\
Göreve Yönelik İletişim & .04 & .11 & .03 & .39 & .69 \\
Bilgilendirmeye Ynelik İlet. & .04 & .15 & .39 & .02 & .97 \\
Geri Bildirim & .26 & .11 & .24 & 2.24 & .02 \\
Tutum ve Dav. Yönelik İlet. & 1.05 & .12 & .94 & 8.55 & .00 \\
\hline
\end{tabular}

$\mathrm{R}=.76^{\mathrm{a}} \mathrm{R}^{2}=.57 \mathrm{~F}=84.64 \mathrm{p}=0.00$

Tablo 5'e göregöreve yönelik iletişim, bilgilendirmeye yönelik iletişim, geri bildirim ve tutum ve davranışa yönelik iletişim değişkenleri ile kişisel gelişim arasında anlamlı bir ilişki bulunmaktadir $\left(\mathrm{R}=.76^{\mathrm{a}} \mathrm{R}^{2}=.57 \mathrm{~F}=84.64 \mathrm{p}<.05\right)$. Geri Bildirim $(\beta=.24, p<.05)$ ve Tutum ve Davranışa Yönelik İletişim $(\beta=.94, p<.05)$ değişkenlerinin kişisel gelişimi yordama gücü istatistiksel olarak anlamlı bulunmuştur. Bu iki değişken birlikte kişisel gelişim toplam varyansının yaklaşık \% 57'sini açıklamaktadır. Göreve yönelik iletişim ve bilgilendirmeye yönelik iletişim ise kuruma bağlılık üzerinde anlamlı bir etkiye sahip değildir.

Örgütsel iletişimin (toplam puan), iş motivasyonunu (toplam puan) yordamasına ilişkin bulgular Tablo 6' da verilmiştir.

Tablo 6. Örgütsel İletişimin (Toplam Puan) Öğretmenlerin İş Motivasyonunu (Toplam Puan) Yordamasına İlişkin Basit Doğrusal Regresyon Analizi Sonuçları

\begin{tabular}{llrccc}
\hline Değişkenler & B & SH & $\boldsymbol{\beta}$ & $\mathbf{t}$ & $\mathbf{p}$ \\
\hline Sabit & .49 & .16 & - & 2.90 & 0.00 \\
Örgütsel İletişim & .87 & .03 & .81 & 22.09 & 0.00 \\
\hline \multicolumn{1}{c}{$\mathrm{R}=.81^{\mathrm{a}} \mathrm{R}^{2}=.66 \mathrm{~F}=488.36$} & $\mathrm{p}=0.00$ & & & &
\end{tabular}

Tablo 6'ya göre örgütsel iletişim (toplam puan) ile öğretmenlerin iş motivasyonu (toplam puan) arasında $\left(\mathrm{R}=.81 \mathrm{R}^{2}=.66, \mathrm{~F}=488.36 \mathrm{p}<0.01\right)$ anlamlı bir ilişki bulunmaktadır. Örgütsel iletişimin (toplam puan) öğretmenlerin iş motivasyonunu (toplam puan) yordama gücü istatistiksel olarak anlamlı bulunmuştur. Örgütsel iletişim, öğretmenlerin iş motivasyonuna ilişkin toplam varyansın \% 66'sını açıklamaktadır.

\section{Tartışma, Sonuç ve Öneriler}

$\mathrm{Bu}$ araştırmada okullarda örgütsel iletişim ile öğretmenlerin iş motivasyonu arasındaki 
ilişkiler incelenmiştir. Araştırma sonuçları, ilkokullarda örgütsel iletişim ile öğretmenlerin iş motivasyonu arasında önemli ilişkiler olduğunu ortaya koymaktadır. Ayrıca okullarda gerçekleşen örgütsel iletişim öğretmenlerin iş motivasyonunu anlamlı şekilde yordamaktadır.

Araştırmanın amaçlarına ilişkin bulgular incelendiğinde, örgütsel iletişimin alt boyutları, iş motivasyonun tüm alt boyutları ile pozitif ilişkilidir. Ayrıca örgütsel iletişimin alt boyutları da öğretmenlerin iş motivasyonunun alt boyutlarını yordamaktadır. Başka bir deyişle, okullarda örgütsel iletişim düzeyi arttıkça, öğretmenlerin iş motivasyonu da artmaktadır. Okuldaki örgütsel iletişim düzeyi öğretmenlerin iş doyumunu açıklamada önemli bir değişkendir. Bu bulgular genel olarak örgütlerde, iletişim ile iş motivasyonu arasında pozitif bir ilişki olduğunu ve iletişimin çalışanların iş motivasyonunu etkilediğini ortaya koyan Rajhans, (2012); Karimi (2013); Chitrao (2014); Mutuku ve Mathooko (2014); Timuroğlu ve Balkaya, 2016); Amadanty ve Martinus'un (2016) araştırma bulgularını desteklemektedir. Mutuku ve Mathooko (2014), örgütlerde başta bilgi paylaşımı olmak üzere çalışanların karara katılmaları ve iletişim kanallarının açık olmasının çalışanların motivasyonunu etkilediğini bulmuşlardır. Chitrao (2014), yöneticilerin çalışanların takdir edildiklerini hissetmeleri ve çalışanları motive etmek için iletişim stratejilerinin önemli olduğunu ortaya koyarak içsel iletişimin çalışanların motivasyonu üzerinde etkili olduğunu bulmuştur. Ramadanty ve Martinus (2016), örgüt içinde yöneticinin sözsüz iletişim ve kişilerarası iletişim becerileri ile iletişim ikliminin çalışanların iş motivasyonunda önemli bir role sahip olduğunu ortaya koymuşlardır. Rajhans (2012), örgütlerde gerçekleşen etkili örgütsel iletişim uygulamalarının, çalışan motivasyonu, performans artışı ve örgütsel bağlılığa önemli katkıları olduğunu ortaya koymuştur. Karimi (2013) da örgütsel iletişimin iş motivasyonu üzerinde etkili olduğunu, motivasyonun da iş memnuniyetine aracılık ettiğini belirtmektedir.

Araştırmanın bulguları, okullarda iletişim ile motivasyon arasındaki ilişkileri konu alan birkaç araştırma sonucuyla da örtüşmektedir. Okullarda eğitim yöneticilerinin iletişim davranışlarının öğretmenlerin motivasyonuyla ilişkili olduğuna ve öğretmen motivasyonlarını etkilediğine yönelik sonuçlar bulan Doğan ve Koçak (2014); Sümer (2012); Özgan ve Aslan (2008); Sabancı (1994); Karaköse ve Kocabaş'ın (2006) araştırma bulguları mevcut araştırma bulgularını destekler niteliktedir. Doğan ve Koçak (2014), ortaokullarda çalışan yöneticilerin sosyal iletişim becerileri ile öğretmenlerin iş motivasyonu arasında pozitif yönde yüksek bir ilişki bulunduğunu ortaya koymuşlardır. Sümer (2012) yaptığı nitel bir araştırmada yöneticilerin iletişim becerilerinin 
öğretmenlerin motivasyonundaki etkisini incelemiştir. Araştırmaya göre katılımcı öğretmenler, uygun iletişimin (seviyeli, uygun üslup, saygılı) kurulmasının kendilerini olumlu yönde motive ettiğini belirterek yöneticilerin iletişimde kullanacakları hitap şeklinin önemli olduğunu vurgulamışlardır. Özgan ve Aslan (2008) yaptıkları nitel araştırmalarında, okul yöneticilerinin iletişim davranışlarının öğretmenlerin motivasyonunu etkilediğini ortaya koymuşlardır. Sabancı (1994), eğitim yönetiminde çift yönlü iletişimin öğretmenlerin iş motivasyonuna etkilerini incelemiştir. Araştırmaya göre eğitim yöneticileri ve öğretmenler arasındaki çift yönlü iletişim ile öğretmenin motivasyonu arasında anlamlı bir ilişki bulunmaktadır. İletişimin az olduğu ortamda iş doyumu ve motivasyon da düşük olmaktadır. Öğretmenlerin karara katılmaları, iş doyumu ve motivasyonu olumlu yönde etkilemektedir. Ayrıca çift yönlü iletişim, öğretmenlerin iş arkadaşlarıyla olumlu ilişkiler geliştirmesine yol açmaktadır. Okul içindeki insan ilişkileri, diğer bir deyişle iletişim ortamı öğretmen motivasyonunu etkileyebilmektedir. Karaköse ve Kocabaş (2006), özel okulda görev yapan yöneticilerin öğretmenleri karara katma, öğretmenlerin görüşlerini alma, öğretmenler olumlu davranışlarda bulunduklarında onları takdir etme gibi iletişime yönelik davranışlarının, öğretmenlerin iş doyumu ve motivasyonunu olumlu yönde etkilediğini ortaya koymaktadır. Bu araştırmanın sonuçları da örgütsel iletişimin öğretmenlerin iş motivasyonlarında oldukça önemli bir yere sahip olduğunu ortaya koymaktadır. Bu bağlamda ulaşılan bulgulardan elde edilen sonuçlar kapsamında uygulayıcı ve araştırmacılara şu önerilerde bulunulabilir:

1. MEB, Milli Eğitim Müdürlükleri, üniversiteler ile iş birliğine giderek okul müdürlerine yönelik örgütsel iletişim ve motivasyonla ilgili hizmet içi eğitimler ve seminerler düzenleyebilir.

2. Okul müdürleri, okulla, öğretmenle ve öğrencilerle ilgili bilgi, haber ve duyuruları okulun web sayfasının yanısıra Facebook, Twitter, WhatsApp gibi sanal platformlarda da paylaşabilirler.

3. Okul müdürleri, okulla ilgili kararlarla ilgili öğretmenleri bilgilendirebilir ve onları alınan kararlara katabilirler ve öğretmenlerle çift yönlü bir iletişim kurabilirler.

4. Okul müdürleri, öğretmenler ile birlikte okul başarısı için her dönem ideal amaç ve hedefler belirlemeli; bunu diğer tüm paydaşlarla paylaşmalıdırlar.

5. Okul müdürleri, öğretmenleri değerlendirirken tarafsız davranmalı; başarılı olanları teşekkür ve takdir belgesi ile ödüllendirmeli; görev dağılımında adaletli olmalıdırlar.

6. Araştırmacılar gelecekteki araştırmalarda, örgütsel iletişim ve iş motivasyonu ile öğretmen tükenmişliği, örgütsel vatandaşlık, bağlılık ve özdeşleşme gibi değişkenler arasındaki ilişkileri inceleyebilirler. 
Okullarda örgütsel iletişim ile öğretmenlerin iş motivasyonları arasındaki ilişkiler

\section{Kaynakça}

Aksoy, H. (2006). Örgüt ikliminin motivasyon üzerine etkisi. (Yayımlanmamış Yüksek Lisans Tezi). Marmara Üniversitesi Sosyal Bilimler Enstitüsü, İstanbul

Anderson, M. B. G., \& Iwanicki, E. F. (1984). Teacher motivation and its relationship to burnout. Educational Administration Quarterly, 20(2), 109-132.

Atkinson, E. S. (2000). An investigation into the relationship between teacher motivation and pupil motivation. Educational Psychology: An International Journal of Experimental Educational Psychology, 20(1), 45-57.

Aydın, M. (2010). Eğitim yönetimi. Ankara: Hatipoğlu Basım yayıncılık.

Ayık, A. (2015). An analysis of the relationship between organizational communication and organizational cynicism according to teachers perceptions in Turkey. Educational Research and Reviews, 10(5), 547-555.

Bishay, A. (1996). Teacher motivation and job satisfaction: A study employing the experience sampling method. Journal of Undergraduate Sciences, 3(3), 147-155.

Büyükses, T. (2010). Öğretmenin iş ortamındaki motivasyonunu etkileyen etmenler. (Yayımlanmamış Yüksek Lisans Tezi), Süleyman Demirel Üniversitesi Sosyal Bilimler Enstitüsü, Isparta.

Canrinus, E. T., Helms-Lorenz, M., Beijaard, D., Buitink, J., \& Hofman, A. (2012). Self-efficacy, job satisfaction, motivation and commitment: exploring the relationships between indicators of teachers' professional identity. European Journal Of Psychology Of Education, 27(1), 115-132.

Celep, C. (2000). Eğitimde örgütsel adanma ve öğretmenler. Ankara: Anı Yayınc1lık.

Chitrao, P. (2014). Internal Communication satisfaction as an employee motivation tool in the retail sector in pune. The European Journal of Social \& Behavioural Sciences, 10(3), 1541.

Daft, R.L. (2005). Management. Ohio: Thomson/South-Western

Davis, J. \& Wilson, M., S. (2000) Principals' efforts to empower teachers: effects on teacher motivation and job satisfaction and stress, The Clearing House: A Journal of Educational Strategies, Issues and Ideas, 73(6), 349-353. 
Demirel, Y., Seçkin, Z., \& Özçınar, M. F. (2011). Örgütsel iletişim ile örgütsel vatandaşlık davranışı arasındaki ilişki üzerine bir araştırma. Çukurova Üniversitesi Sosyal Bilimler Enstitüsü Dergisi, 20(2), 33-48.

Doğan, S., \& Koçak, O. (2014). Okul yöneticilerinin sosyal iletişim becerileri ile öğretmenlerin motivasyon düzeyleri arasındaki ilişki. Kuram ve Uygulamada Egitim Yönetimi Dergisi, 20(2), 191-216.

Ertürk, R.(2014). Öğretmenlerin iş motivasyonları ile örgütsel bağlllıkları arasındaki ilişki (Bolu ili örneği). (Yayımlanmamış Yüksek Lisans Tezi), Abant İzzet Baysal Üniversitesi, Eğitim Bilimleri Enstitüsü, Bolu.

Erel-Yetim E. A. (2010). Genel liselerde örgütsel iletişim ile örgütsel özdeşleşme arasındaki iliş̧ki. (Yayımlanmamış Yüksek Lisans Tezi), Gazi Üniversitesi Eğitim Bilimleri Enstitüsü, Ankara

Eroğluer, K. (2011). Örgütsel iletişim ile iş tatmini unsurları arasındaki ilişkiler: Kuramsal bir inceleme. Ege Akademik Bakış, 11(1), 121-136.

Eyal, O., \& Roth, G. (2011). Principals' leadership and teachers' motivation: Self-determination theory analysis. Journal of Educational Administration, 49(3), 256-2.

Genç, N. (2007). Yönetim ve organizasyon. Ankara: Seçkin Yayınevi

Güçlü, N., Recepoğlu, E., \& Kılınç, A. Ç. (2014). İlköğretim okullarının örgütsel sağlı̆̆ı ile öğretmenlerin iş motivasyonları arasındaki ilişki. Hacettepe Üniversitesi Eğitim Fakültesi Dergisi, 29(29-1).

Güney, S. (2011). Örgütsel davranış. Ankara: Nobel Yayın Dă̆ı̆ım.

Hoy, K. W. \& Miskel, G. C. (2010). Eğitim yönetimi, teori araştırma ve uygulama. (Çev. Edt. Selahattin Turan). Ankara: Nobel Yayın Dağıtım.

Karaköse T. \& Kocabaş İ. (2006). Özel ve devlet okullarında öğretmenlerin beklentilerinin is doyumu ve motivasyon üzerine etkileri. Eğitimde Kuram ve Uygulama Dergisi, 2 (1), 3-14.

Karcıoğlu, F., Timiroğlu, K., \& Çınar, O. (2009). Örgütsel iletişim ve iş tatmini ilişkisi bir uygulama. İstanbul Üniversitesi İşletme İktisadi Enstitüsü Dergisi-Yönetim, 63, 59-76.

Karimi, M. J. (2013). The impact of communication on employee motivation in The Kenyan public service: a case study of postal Corporation of Kenya. Doctoral dissertation, University of Nairobi, Kenya. 
Leithwood, K., Steinbach, R., \& Jantzi, D. (2002). School leadership and teachers' motivation to implement accountability policies. Educational Administration Quarterly, 38(1), 94-119.

Lunenburg, F. C., \& Ornstein, A. C. (2013). Eğitim yönetimi (Çev. Arastaman, G.). Ankara: Nobel Yayınlar1.

Mutuku, C. K. \& Mathooko, P. (2014). Effects of organizational communication on employee motivation: A case study of Nokia Siemens Networks Kenya. International Journal of Social Sciences and Project Planning Management, 1(3), 28-62.

Oran, F. Ç., Güler, S. B., \& Bilir, P. (2016). İş motivasyonun örgütsel bağlılığa olan etkinin incelenmesi: sultangazi/istanbul ilköğretim okullarında bir araştırma. Mustafa Kemal Üniversitesi Sosyal Bilimler Enstitüsü Dergisi, 13(35), 236-252.

Özgan, H. \& Aslan, N. (2008). İlköğretim okul müdürlerinin sözlü iletişim biçiminin öğretmenlerin motivasyonuna etkisinin incelenmesi. Gaziantep Üniversitesi Sosyal Bilimler Dergisi, 7(1), 190-206.

Pinder, C. C. (2014). Work motivation in organizational behavior. Psyhology Press. New York.

Proctor, C. (2014). Effective organizational communication affects employee attitude, happiness, and job satisfaction. (Doctoral dissertation), Southern Utah University.

Rajhans, K. (2012). Effective organizational communication: A key to employee motivation and performance. Interscience Management Review, 2(2), 81-85.

Ramadanty, S., \& Martinus, H. (2016). Organizational communication: communication and motivation in the workplace. Humaniora, 7(1), 77-86.

Ridder, J. A. (2004). Organisational communication and supportive employees. Human Resource Management Journal, 14(3), 20-30.

Robbins, P. S., Decenzo, A. D., \& Coulter, M. (2013). Yönetimin esasları. (Çev. Edt. A. Öğüt). Ankara: Nobel Yayın Dağıtım.

Robbins, S. P. \& Judge, T. A. (2012). Örgütsel davranış. (Çev. Edt: İ. Erdem) İstanbul: Nobel Akademik Yayıncılık.

Sabanc1, A. (1994). Eğitim yönetiminde çift yönlü iletişim yönetilenleri iş doyumu motivasyon bakımından nasıl etkilemektedir? (Yayımlanmamış Yüksek Lisans Tezi), İnönü Üniversitesi Sosyal Bilimler Enstitüsü, Malatya.

Sabuncuoğlu, Z. \& Gümüş, M. (2008). Örgütlerde iletişim. İstanbul: Arıkan Basım Yayın. 
Sharma, P. R. (2015). Organizational communication: perceptions of staff members' level of communication satisfaction and job satisfaction. Doctoral dissertation, East Tennessee State University, ABD.

Sümer, B. (2012). KKTC ortaöğretim kurumları yöneticilerinin düşünce ve davranışlarının öğretmenlerin motivasyonuna etkisinin değerlendirilmesi. (Yayımlanmamış Yüksek Lisans Tezi), KKTC Yakındoğu Üniversitesi Eğitim Bilimleri Enstitüsü, Kıbrıs.

Taşlıyan, M., \& Hırlak, B. (2015). Örgütsel iletişim etkinliği ile iş tatmini, örgütsel bağl1lık, örgütsel vatandaşlık davranışı arasındaki ilişkilerin araştırılması: akademik örgütler için bir alan araştırması. Muğla Sıtkı Koçman Üniversitesi İktisadi ve İdari Bilimler Fakültesi Ekonomi ve Yönetim Araştırmaları Dergisi, 3(2), 5-36.

Timuroğlu, K.M., \& Balkaya, E. (2016). Örgütsel iletişim ve motivasyon ilişkisi -bir uygulama. U.Ü. Sosyal Bilimler Enstitüsü Dergisi, 9 (2), 89-113.

Tınaztepe, C. (2012). Örgüt içi etkin iletişimin örgütsel sinizme etkisi. Organizasyon ve Yönetim Bilimleri Dergisi, 4(1), 53-63.

Tutar, H. (2003). Örgütsel iletişim. Seçkin Yayıncılık: Ankara.

Uslu, B., \& Balcı, E. (2012). İlköğretim okulu öğretmenlerinin örgütsel vatandaşlık davranışları ile örgütsel iletişim algıları arasındaki ilişki. Kuram ve Uygulamada Eğitim Yönetimi Dergisi, 18(3), 461-489.

Wasserman, E., Ben-eli, S., Yehoshua, O., \& Gal, R. (2016). Relationship between the Principal's leadership style and teacher motivation. International Journal of Learning, Teaching and Educational Research, 15(10), 180-192.

Yavuz, C., \& Karadeniz, C. B. (2009). Sınıf öğretmenlerinin motivasyonunun iş tatmini üzerine etkisi. Journal of International Social Research, 2(9), 507-519.

Yılmaz, F. (2009). Eğitim örgütlerinde örgüt kültürünün öğretmenlerin iş motivasyonu üzerindeki etkisi. (Yayımlanmamış Yüksek Lisans Tezi), Selçuk Üniversitesi, Sosyal Bilimleri Enstitüsü, Konya. 